\title{
Magnitude of tuberculosis on the Bioceanic Route: an epidemiological description
}

\author{
Magnitude da tuberculose na Rota Bioceânica: uma descrição epidemiológica
}

Magnitud de la tuberculosis en la Ruta Bioceánica: una descripción epidemiológica

\author{
João Pedro Arantes Cunha ${ }^{1}$ \\ Rafael Vilela de Campos ${ }^{1}$ \\ Ruberval Franco Maciel ${ }^{1}$ \\ Ana Maria Campos Marques ${ }^{1}$
}

Received on 3 Aug. 2021; revised and approved on 18 Sept. 2021; accepted on 13 Oct. 2021

DOI: http://dx.doi.org/10.20435/inter.v22i4.3475

\begin{abstract}
This study aims to assess the epidemiological situation of five municipalities that are part of the Bioceanic Route in order to analyze the descriptors and general health aspect of the population through a retrospective, quantitative and cross-sectional descriptive study with a documentary approach, from secondary data reported to the National System of Notifiable Diseases in the municipalities of Guia Lopes da Laguna, Jardim, Nioaque, Porto Murtinho, Sidrolândia and Campo Grande, in the state of Mato Grosso do Sul, in the period from January 2015 to December 2020. The incidence rate ranged between 32.23 and 79.4 cases/100,000 inhabitants. There was a predominance of individuals aged between $30-39$ years $(26.05 \%)$ and males (67.5\%). The most important injuries were alcoholism (19.15\%) and smoking (18\%). In the exams, $52.3 \%$ had positive bacilloscopy and $32.03 \%$ had a positive culture. The incidence of tuberculosis in the evaluated municipalities was higher than the Brazilian average and that of the state of Mato Grosso do Sul. These evaluated municipalities do not have a favorable epidemiological situation with regard to tuberculosis and the construction of the biocenic route may further aggravate the situation.
\end{abstract}

Keywords: tuberculosis; epidemiology; Bioceanic Route.

Resumo: Este estudo tem como objetivo avaliar a situação epidemiológica de cinco municípios que fazem parte da Rota Bioceânica a fim de analisar os descritores e aspecto geral de saúde da população por meio de um estudo retrospectivo, quantitativo e transversal, do tipo descritivo e de abordagem documental, a partir de dados secundários notificados ao Sistema Nacional de Agravos de Notificação nos municípios de Guia Lopes da Laguna, Jardim, Nioaque, Porto Murtinho, Sidrolândia e Campo Grande, no estado de Mato Grosso do Sul, no período compreendido entre janeiro de 2015 a dezembro de 2020. A taxa de incidência variou entre 32,23 e 79,4 casos/100mil habitantes. Predominaram indivíduos entre 30-39 anos (26,05\%) e sexo masculino (67,5\%). Os agravos mais importantes foram alcoolismo (19,15\%) e tabagismo (18\%). Nos exames, 52,3\% apresentaram baciloscopia positiva e 32,03\% cultura positiva. A incidência de tuberculose nos municípios avaliados foi maior do que a média brasileira e a do estado de Mato Grosso do Sul. Esses municípios avaliados não possuem uma situação epidemiológica favorável com relação à tuberculose e a construção da rota bioceânica pode agravar ainda mais a situação.

Palavras-chave: tuberculose; epidemiologia; Rota Bioceânica.

Resumen: Este estudio tiene como objetivo evaluar la situación epidemiológica de cinco municipios que forman parte de la ruta bioceánica con el fin de analizar los descriptores y aspecto de salud general de la población a través de un estudio descriptivo retrospectivo, cuantitativo y transversal con enfoque documental, a partir de datos secundarios. Reportados al Sistema Nacional de Enfermedades de Notificación en los municipios de Guia Lopes da Laguna, Jardim, Nioaque, Porto Murtinho, Sidrolândia y Campo Grande, en el estado de Mato Grosso do Sul, en el período de enero de 2015 a diciembre de 2020. La incidencia la tasa osciló entre 32,23 y 79,4 casos / 100.000 habitantes. Predominó el grupo de personas de 30 a 39 años (26,05\%) y el sexo masculino (67,5\%). Las lesiones más importantes fueron el alcoholismo $(19,15 \%)$ y el tabaquismo (18\%). En los exámenes, el 52,3\% tenía baciloscopia positiva y el 32,03\% tenía cultivo positivo. La incidencia de tuberculosis en los municipios evaluados fue superior al promedio brasileño y al del estado de Mato Grosso do Sul. Estos municipios evaluados no tienen una situación epidemiológica favorable con respecto a la tuberculosis y la construcción de la ruta bioceánica puede agravar aún más la situación.

Palavras clave: tuberculosis; epidemiologia; Ruta Bioceânica.

\footnotetext{
${ }^{1}$ Universidade Estadual de Mato Grosso do Sul Campo Grande, Mato Grosso do Sul, Brasil.
} 


\section{INTRODUCTION}

The Bioceanic Road Corridor, also called Latin American Integration Route (RILA) or Bioceanic Route, is a road corridor with a length of 2,396 kilometers, which intends to connect the Atlantic Ocean to the ports of Antofagasta and Iquique, in Chile, passing through Paraguay and Argentina, comprising four countries: Brazil, Paraguay, Argentina and Chile. Its objective is the construction of state cooperation and integration of the South American continent, initially known as Regional Infrastructure Integration, composing a corridor or an integration route with the flow of production from these countries through the Pacific Ocean, thus minimizing operating costs, financial, enabling integration of the continent and also reducing the route to Asia, which leads to a reduction in time for production to arrive (ASATO et al., 2019; FERREIRA; CASTILHO; OLIVEIRA, 2019).

The Route has been a topic of discussion in Brazil and, specifically in Mato Grosso do Sul, since the mid-2000s. However, it was only in 2017 that the theme matured and, more specifically in this office, the emphasis returned to the potential of effectiveness of the same to the state. Its operation is initially driven by a bias towards the activity of logistics and transport as an alternative to transporting grains and promoting a more accelerated distribution of production and, secondly, by tourism. With its completion, the vector of the Corridor is to connect Mato Grosso do Sul, on the border of Porto Murtinho with the Republic of Paraguay, from a new binational bridge, passing through Paraguay and Argentina until reaching Chile. Its construction will increase the Mato Grosso do Sul economy, in relation to logistics companies and in the strengthening of new tourist potentials (ASATO, et al., 2019; FERREIRA; CASTILHO; OLIVEIRA, 2019).

Many studies claim that there is potential for economic growth with the construction of the Route, however, they indicate the possibility of social problems such as sexual exploitation, urban violence, basic sanitation and lack of access to goods and services, a panorama that can be intensified in the absence of public policies that accompany the process (ASATO, et al., 2019; FERREIRA; CASTILHO; OLIVEIRA, 2019).

Located in the Brazilian Central-West Region, Mato Grosso do Sul borders Paraguay and Bolivia, covering a total length of $1.578 \mathrm{~km}$, along which 12 municipalities are located, including Porto Murtinho, Ponta Porã and Mundo Novo. According to the 2010 Demographic Census, the state had 2.449 .024 inhabitants, $12.5 \%$ of whom lived in the border municipalities and $87.5 \%$ in the other interior municipalities and capital (MARQUES et al., 2014).

The intense flow of people and movement of people along the Bioceanic Route contributes to a greater circulation of pathogens such as Mycobacterium tuberculosis, the causative agent of tuberculosis, which is among the most prevalent infectious diseases worldwide. According to the World Health Organization [WHO] (2011), one third of the world population is infected with Mycobacterium tuberculosis, and the annual number of incidence is estimated at about 8.8 million per year (OLIVEIRA et al., 2014). In this scenario, approximately one third of sick individuals have a positive bacilloscopy, characterizing active tuberculosis and, therefore, they can be transmitters of the disease.

Regarding advances in diagnosis and treatment, tuberculosis remains one of the main health problems globally and one of the most important causes of death in underdeveloped and developing countries. In Brazil, the disease follows the global pattern of decline, although in some population segments its concentration levels exceed the national average, especially in the homeless, indigenous, black and prison population, as well as in those with Human 
Immunodeficiency Virus (HIV) and other associated diseases/diseases, such as smoking and alcoholism (MARQUES et al., 2014). In addition, Brazil is one of the 22 countries that concentrate $80 \%$ of the global burden of the disease, with an algorithm of 4.500 deaths per year (BRASIL, 2020).

Although Brazil has experienced a certain reduction in the incidence of the disease over the past few years, the problem is still far from being eliminated. In 2015, more than 63 thousand new cases of tuberculosis were diagnosed, among which 6.800 in people living with HIV (BRASIL, 2016).

The disease is transmitted from the expulsion of bacilli through the respiratory route and among the factors that contribute to the transmission, urban settlements, poor sanitary conditions, poor access to health services and associated comorbidities such as alcoholism, diabetes mellitus, smoking stand out, the use of illicit psychoactive substances and, mainly, HIV coinfection (OLIVEIRA et al., 2014). Faced with this statement, populations with low socioeconomic conditions are those with greater risk/vulnerability to contract the disease.

In accordance with the clinical and epidemiological data on tuberculosis in the world driven by the epidemic of people living with HIV at the time, the WHO declared tuberculosis a world emergency in 1993. In 2003, the Ministry of Health established the disease as one of the five diseases control priorities in the country, inserting it in projects and action plans, in addition to gathering information and activities in the National Tuberculosis Control Program (PNCT). Among the main objectives of the PNCT are the establishment of the goal of curing $85 \%$ of the sick and having an incidence below 25.6 cases per 100.000 population by 2015 , which has not been met so far, in addition to reducing the dropout rate treatment and avoid the emergence of resistant bacilli, thus enabling the effective control of the disease (BRASIL, 2003; GASPAR et al., 2016).

Therefore, it is possible to conclude that the diagnosis and treatment success rates remain stagnant, characterizing the inefficiency of the health system acting in the clinical course of the disease. Therefore, it becomes more viable to encourage the development and adaptation of new proposals that aim to alleviate this problem in the country, eradicating the transmission of the disease and reducing the delay in its diagnosis. This context points to the primordiality of constant surveillance of epidemiological indicators, whose monitoring allows assessing the results of actions and the magnitude of the problem in a given location, proposing health plans and policies that can impact on the reduction of incidence rates, prevalence and mortality (SILVA et al., 2017).

In 2017, 1148 new cases of Tuberculosis (TB) were registered in the state of Mato Grosso do Sul (MS). Interspersed with this numbered, we sought to relate this incidence by the municipalities in the state that are part of the RILA, to obtain concrete data regarding the situation of these populations in the field of health, based on the epidemiological bulletin of Mato Grosso do Sul.

In this context, this research project intends to evaluate the epidemiological situation of the interior municipalities of Mato Grosso do Sul inserted in the context of the Route, so that it is possible to analyze the descriptors and the health situation of their population, as well as the related sociocultural aspects, which can interfere directly and indirectly with the socioeconomic objectives of the expanding Corridor.

Therefore, considering the environmental, social, economic, demographic and cultural particularities that contribute to the diversity of diseases and their behavior in each region, as well as the lack of recent analysis of the data provided by the Notifiable Diseases Information System (SINAN), this research aims to describe the magnitude of tuberculosis in the period 2015- 
2020 in six Brazilian municipalities in Mato Grosso do Sul located on the Route's expansion line, bordering the border with Paraguay, estimating the incidence of tuberculosis and its diseases and associated health problems reported in the health services of the municipalities in the state of Mato Grosso do Sul that are part of the Bioceanic Route.

As the Route is an important geographic-economic resource with great translocation, movement and transit of people, it is hypothesized the increase in the incidence of TB in these municipalities that make up this large route for the movement of people, goods and products of international commercial value. For this reason, this study aimed to estimate the incidence of TB and the main comorbidities and health problems in the five municipalities in the state that are part of the Bioceanic Corridor.

\section{METHODS}

The research was carried out through a retrospective, quantitative and cross-sectional, descriptive and documentary approach, based on secondary data, as it analyzed the epidemiological and sociodemographic profile of patients diagnosed with tuberculosis and associated diseases in health services of the municipalities analyzed and notified in the National System of Notifiable Diseases (SINAN). The sample consisted of all cases of tuberculosis diagnosed, notified and registered in the SINAN database in the municipalities of Guia Lopes da Laguna, Jardim, Nioaque, Porto Murtinho, Sidrolândia and Campo Grande, in the state of Mato Grosso do Sul, in the period from January 2015 to December 2020. The database was provided by the State Health Department of Mato Grosso do Sul, headquartered in Campo Grande, MS (SES/ CG-MS), as standardized by the Ministry of Health.

The analyzed variables contained in the SINAN database included sociodemographic and epidemiological data, such as gender, age, ethnicity, education, occupation/profession, reporting health unit, origin of cases, type of entry (new case, abandonment, recurrence and others), forms of TB (pulmonary and extrapulmonary), diseases and associated diseases, such as diabetes, hypertension, smoking, HIV, alcoholism and use of psychoactive substances, tests performed for diagnosis.

For data analysis, Bioestat 5.0 and Excel 2016 were used. The population data needed to calculate the indicators were obtained through the Brazilian Institute of Geography and Statistics (IBGE), using the 2010 census and inter-census projections for the other years of the time series. Cases with altered diagnosis, transfers, duplicate notifications and patients not residing in the respective municipalities were excluded from the research. To calculate the incidence coefficient, the total number of cases/100.000 inhabitants and the IBGE population base were used. Project approved by the Research Ethics Committee (CEP) and National Research Ethics Commission (CONEP), n. 4.728.030/May 2021. STROBRE checklist was used for observational and crosssectional studies in epidemiology to assess the merits of the research.

\section{RESULTS}

Between 2015 and 2020 there were 261 notifications as follows in the municipalities covered by the survey: 18 patients (6.89\%) from Guia Lopes da Laguna, 119 from Jardim (45.59\%), 16 from Nioaque (6,13\%), from Porto Murtinho 23 cases (8.81\%), from Sidrolândia there were 46 (17.62\%), from Campo Grande there were 39 cases (14.94\%), all of whom were residents of the 
other 5 municipalities already mentioned: 1 from Guia Lopes da Laguna, 6 from Jardim, 10 from Nioaque, 5 from Porto Murtinho and 17 from Sidrolândia. Considering the city of origin, 19 cases came from Lopes da Laguna guide (7.27\%), 125 cases from Jardim (47.89\%), 26 from Nioaque (9.96\%), 28 from Porto Murtinho (10, 72\%), 63 from Sidrolândia (24.13\%).

In the chronological comparison of TB cases, 34 occurred in 2015 (14.52\%), 45 in 2016 (19.23\%), 38 in 2017 (16.23\%), 52 in 2018 (22.22\%), 49 in 2019 (20.94\%), 43 in 2020 (18.37\%). New cases corresponded to 210 of the total notifications, 1 case was notified after death, 17 were relapses, 18 relapses after treatment dropout, and 17 transfers.

Of this population, 30 were deprived of liberty (11.49\%) and 5 (1.91\%) were homeless. A total of $222(85.05 \%)$ lived in an urban area, 36 (13.79\%) in a rural area and only 1 in a periurban area.

The distribution by sex/gender, 175 (67.05\%) were male and 86 (32.95\%) were female. Taking into account the age at diagnosis, between 0 and 19 years, 7 cases (2.68\%) were reported, between 10 and 19 years, 12 cases (4.59\%), between 20 and 29 years, 50 cases (19.15\%), between 30 and 39 years, 68 cases (26.05\%), between 40 and 49 years, 44 cases (16.85\%), between 50 and 59 years, 46 cases (17.62\%), and over 60 years, totaled 35 cases (13.4\%). According to the declared ethnicity, 149 were brown (57\%), 77 white (29.5\%), 16 black (6.13\%), 16 indigenous (6.13\%), 1 yellow $(0.38 \%)$ and 2 ignored $(0.76 \%)$.

Table 1-Distribution of all tuberculosis cases reported to Sinan in the municipalities of the Bioceanic Route from 2015 to 2020 according to gender and age group

\begin{tabular}{|l|c|c|}
\hline \multicolumn{1}{|c|}{ Sex and age } & N & $\%$ \\
\hline Total of cases & 264 & $100 \%$ \\
\hline Sex: & 86 & $32,95 \%$ \\
\hline Female & 175 & $67,05 \%$ \\
\hline Male & 7 & $2,68 \%$ \\
\hline Group age & 12 & $4,59 \%$ \\
\hline $0-19$ years old & 50 & $19,15 \%$ \\
\hline 10-19 years old & 68 & $26,05 \%$ \\
\hline 20-29 years old & 44 & $16,85 \%$ \\
\hline $30-39$ years old & 46 & $17,62 \%$ \\
\hline $40-49$ years old & 35 & $13,4 \%$ \\
\hline $50-59$ years old & & \\
\hline Over 60 years &
\end{tabular}

Source: The authors, 2021.

Regarding the education of the individuals studied, 36 had completed the 1 st to 4 th grade of elementary school (13.79\%), 9 had the 4 th grade of complete elementary school (3.44\%), 41 had the 5 th the incomplete 8th grade of elementary school (15.7\%), 18 had completed elementary school (6.89\%), 25 had completed high school (9.57\%) and 17 had not completed high school (6.51\%) , 5 had completed higher education (1.91\%) and 3 had incomplete higher education (1.14\%), 14 were illiterate (5.36\%), 70 were ignored (26.81\%), 18 were blank (6.88\%) and in 5 the question does not apply (1.91\%).

Of this population, 136 patients (52.1\%) were bacilliferous and 90 patients (34.84\%) had previous comorbidities. Of the comorbidities, 23 patients had already been diagnosed with HIV, 
8 were ignored and the remainder, 230, did not have the disease. At the time of the consultation, the serology for HIV was performed, in this, 28 were positive (10.7\%), 22 were not performed (8.42\%), 1 was ignored (0.38\%), 209 were negative (80.07\%) and 1 in progress $(0.38 \%)$. Regarding alcoholism, 50 patients (19.15\%) had this habit, 12 were ignored (4.51\%) and the rest did not have the same. About smoking, 47 patients smoked (18\%), 13 were ignored (4.98\%) and the rest did not. 14 patients were diabetic (5.36\%), 11 were ignored $(4.21 \%)$ and the rest did not have the disease. 19 patients used illicit drugs (7.27\%), 230 did not use them (88.12\%) and the rest were ignored. Of the 22 patients with pleural TB, 12 had comorbidities (54.54\%), the main one being HIV, with 8 cases (66.66\%).

Table 2 - Distribution of reported cases of tuberculosis in the municipalities of the Bioceanic Route from 2015 to 2020 according to the comorbidities studied

\begin{tabular}{|l|c|c|}
\hline \multicolumn{1}{|c|}{ Comorbidities } & N & $\%$ \\
\hline Previous comorbidities: & 23 & $8,7 \%$ \\
\hline HIV & 50 & $19,15 \%$ \\
\hline Alcoholism & 47 & $17,80 \%$ \\
\hline Smoking & 14 & $5,30 \%$ \\
\hline Diabetes & 19 & $7,19 \%$ \\
\hline Illicit drug use & 28 & $10,7 \%$ \\
\hline HIV serologies at the diagnosis of Tuberculosis: \\
\hline Positive & 209 & $80,07 \%$ \\
\hline Negative & 22 & $8,3 \%$ \\
\hline Not realized & \multicolumn{2}{|c|}{} \\
\hline
\end{tabular}

Source: The authors, 2021.

Sputum sputum smear microscopy was performed at the time of diagnosis in 210 cases (80.45\%), considering the patients with the bacillus, with the form of pulmonary tuberculosis. Of these, 135 were positive (62.28\%), 75 negative (35.71\%). Regarding sputum culture, it was performed in 156 cases (59.77\%), 81 were positive (51.92\%) and 64 were negative (41.02\%), while the remainder was in progress at the time of notification.

Chest radiography was performed in 211 cases (77.1\%). Of the chest X-rays performed, 184 were suspicious (87.2\%), 12 were normal (5.68\%), 7 were compatible with another pathology (3.31\%), and 50 were not performed (19.15\%). 241 patients were diagnosed with the pulmonary form $(92.33 \%)$, pulmonary form associated with the extrapulmonary form were 7 (2.66\%), extrapulmonary only 15 (5.74\%) and 1 unknown (0.38\%).

Regarding the form of closure of the disease, 139 were cured (53.25\%), 5 in primary abandonment (1.91\%), 35 in abandonment (13.4\%), 12 with a change of diagnosis (4.59\%) , 2 with schema change $(0.76 \%)$, 5 in death from other causes $(1.91 \%), 8$ in death from TB $(3 \%), 34$ in transfer (13\%) and 21 without registration (8, 04\%). 
Table 3 - Form of closure of tuberculosis cases diagnosed on the Bioceanic Route from 2015 to 2020

\begin{tabular}{|l|c|c|}
\hline \multicolumn{1}{|c|}{ Closing form } & N & \% \\
\hline Healing & 139 & $53,25 \%$ \\
\hline Abandonment & 35 & $13,4 \%$ \\
\hline Primary abandonment & 5 & $1,91 \%$ \\
\hline Diagnostic change & 12 & $4,59 \%$ \\
\hline Change of scheme & 2 & $0,76 \%$ \\
\hline Death from tuberculosis & 8 & $3 \%$ \\
\hline Death from other causes & 5 & $1,91 \%$ \\
\hline Transfer & 34 & $13 \%$ \\
\hline Not registered & 21 & $8,04 \%$ \\
\hline
\end{tabular}

Source: The authors, 2021.

\section{DISCUSSION}

Regarding the analyzed municipalities that are part of the Bioceanic Route, Jardim was the main one (45.59\% of the cases in the study), which characterized a rate of 79.4 cases/100 thousand inhabitants in the average of six years. This increased number can be explained by the fact that the city has a service-based economy. The least affected city in the corridor was Guia Lopes da Laguna, with an average of 32.23 cases/100.000 inhabitants, as it is a city with low population density and an economy based on agriculture and public services (IBGE, 2020).

Comparing with the levels throughout the national territory, in the year 2018 there were 72.788 new cases of tuberculosis with a rate of 34.8 cases/100 thousand inhabitants. While in the state of Mato Grosso do Sul, also in 2018 there were 1061 cases, with a rate of 38.7/100 thousand inhabitants. Thus, the rate in the municipality of Jardim is significantly higher than in the rest of the country and a place to target public policies to combat TB, especially with the construction of the Bioceanic Corridor and the consequent greater movement of people.

Based on the IBGE estimate, comparing the year 2018, the rate of cities evaluated on the bioceanic route was 41.2 cases/100,000 inhabitants, which represented an increase of $6.45 \%$ compared to the value of $38.7 / 100$ thousand inhabitants evaluated as an average in the entire state of Mato Grosso do Sul.

Therefore, these municipalities do not have a favorable epidemiological situation in relation to tuberculosis and the construction of the Bioceanic Corridor may be an aggravating factor for an increase in these numbers, due to the large translocation and transit of people that naturally generate an increase in the circulation of causative pathogens of several diseases, including tuberculosis. Therefore, it is necessary that this region receive special attention from the health authorities, seeking to control the circulation of bacilli in these places with great potential for the flow of people and goods.

The number of cases per year shows a trend of stabilizing numbers, even in the face of public policies aimed at combating tuberculosis at the national level, such as the National Tuberculosis Control Program (PNCT) (GASPAR et al., 2016).

In the characteristics of the population studied, young age was a protective factor, given that only $7.27 \%$ of cases were in children aged $0-19$ years, which can be explained by the competent immunity in this age group. The highest rates were in individuals between $20-29$ and between 
30-39 years old, which is in agreement with several studies that have already been carried out, which also showed a trend towards a greater number of cases in individuals in this age group, with a tendency to fall after that age, since they are more exposed to paid work and because of their social life habits (CECÍLIO et al., 2018).

Furthermore, males had a rate of 2.03 cases for each case in women, which is in accordance with WHO estimates, which varies in a rate between 1.5:1 and 2.1:1, a fact which can be explained by the riskier social behavior of this group and the neglect of their own health (FREITAS et al., 2016).

In the studied population, alcoholism was the most prevalent condition with $19.15 \%$ of the studied group, which corroborates the studies already produced, this association between alcohol and tuberculosis can be explained by the strong link between substance abuse as a predictor abandonment, irregular use of medications, increased risk of illicit drug use, social determinants such as homelessness and malnutrition. This combines a higher risk of infection with a lower immunological and nutritional capacity to protect against the disease (COUTO et al., 2014).

Soon after, smoking was present in $18 \%$ of patients, being considered the condition most associated with tuberculosis in several studies, since tobacco combustion and the consequent inhalation of smoke promote ciliary dysfunction and consequent decrease in the immune response with reduction of phagocytic activity of macrophages and reduction or not of CD4 count (NOVONTY et al., 2017).

The prevalence of diabetes mellitus (DM) found in the study was 5.30\%, which contradicts the average association of this condition with tuberculosis according to most authors, which is usually around $15 \%$, a fact that may be explained by underdiagnosis of diabetes, especially in inner cities, in addition to possible failures in filling out the database or poorly collected clinical history (PEREIRA et al., 2016)

Co-infection with HIV occurred in $11.98 \%$ of the cases carried out in the study, while the prevalence of HIV in the general population is around $0.4 \%$, which is in line with the estimate that a person with HIV has 28 times more likely to contract TB than a person who does not have HIV, making HIV a major risk factor for developing TB (BRASIL, 2020).

In this study, only $13.96 \%$ lived in rural areas while $84.06 \%$ in urban areas, the result found is in accordance with the epidemiological profile of tuberculosis in Brazil, since uncontrolled urbanization and the consequent formation of population clusters were determining factors for the increase in tuberculosis cases in the world (BRASIL, 2019). On the other hand, residents of rural areas live with precarious access to health, a factor that contributes to the still expressive numbers in this population group.

Regarding the forms of tuberculosis found, $8.63 \%$ of the individuals had extrapulmonary forms and $91.64 \%$ had pulmonary forms. According to the world health organization, $90 \%$ of existing patients are pulmonary, a result close to what was found in this study (GIROTI et al., 2010).

In addition, it was possible to observe a strong relationship between the presence of comorbidities with extrapulmonary tuberculosis, as in this group $57.14 \%$ of them had some adjacent condition, compared to $36.79 \%$ in the group with pulmonary TB. HIV was the condition most associated with extrapulmonary tuberculosis (38.09\% of cases), while it was present in only $7.69 \%$ of cases of pulmonary TB, which proves the strong relationship of extrapulmonary forms with immunodeficiency due to HIV (GOMES, 2013).

In the laboratory confirmation of tuberculosis, of the patients evaluated for sputum smear microscopy, $52.3 \%$ of them had positive sputum smear microscopy, a number similar to the 
53.6\% found throughout Brazil in 2018 and the percentage of $48.2 \%$ evaluated in the state of Mato Grosso do Sul in the same period (BRASIL, 2020).

With regard to culture, this number is even lower, since it was performed in only $58.21 \%$ of cases and of the total number of patients, only $32.03 \%$ had a positive culture. These numbers demonstrate the challenges faced in health in Brazil, the difficulty of laboratories in carrying out a significant number of exams, in view of the precariousness of services, difficulty in acquiring supplies, transport and establishment of logistics between laboratories and health units (BRASIL, 2019).

According to the goals established by the world health organization and agreed by the Brazilian authorities, $85 \%$ of the estimated cases of tuberculosis must be cured and in this study the percentage of cure was $72.16 \%$ (discarding cases of change of diagnostics, transfer and schema switching).

In addition, it is recommended that the average rates of treatment dropout be lower than $5 \%$ and the study rate was $17.09 \%$, which demonstrates an inefficiency of public policies, professionals working in the area and awareness of the affected population following treatment (BRASIL, 2019).

\section{CONCLUSION}

The construction of the Bioceanic Corridor may be an aggravating factor for the increased incidence of TB. These municipalities do not have a favorable epidemiological situation or physical structure in relation to the disease, with low rates of early diagnosis in the cities of origin, as a high percentage of cases are referred from the capital. Therefore, it is necessary that this region receive special attention from the health authorities, seeking to control the circulation of bacilli in these places with great potential for the flow of people and goods.

The low cure rate and high dropout rate, which are directly related to each other, provide a greater number of contacts, the cost of treatment and allows the emergence of drug resistance, which creates an even greater difficulty in the treatment and a greater expenditure of funds by the population and the State in combating this disease.

The predominant incidence of alcoholism, smoking and HIV/AIDS is supported in the literature and dialogues with risk factors for illness and treatment failure, whether due to diseases, negligence, higher incidence in males, and points to the need for health services implement their actions for prevention, diagnosis and adequate treatment of these risk factors and comorbidities, not only when diagnosing, but prior to becoming ill with TB, in addition to the need to restructure the set of actions articulated in the health network that aim to implement the early diagnosis of tuberculosis in primary health care units in the cities of origin, actions that are essential to obtain a reduction in the incidence of the disease.

\section{REFERENCES}

ASATO, Thiago Andrade; CONSTANTINO, Michel; DORSA, Arlinda Cantero; MARIANI, Milton Augusto Pasquotto. Rota de Integração Latino-Americana (RILA) para o desenvolvimento turístico. Interações, Campo Grande, MS, v. 20, n. special, p. 45-56, 2019.

BRASIL. Ministry of Health. Boletim Epidemiológico: Tuberculose. Secretariat of health surveillance. Ministry of Health. Special number. March, 2020. 
BRASIL. Ministry of Health. Secretariat of health surveillance. Department of epidemiological surveillance. Manual de recomendações para o controle da tuberculose no Brasil. 2. ed. Brasília, DF: Ministério da Saúde; 2019.

BRASIL. Ministry of Health. Secretariat of health surveillance. Perspectivas brasileiras para o fim da tuberculose como problema de saúde pública. Brasília: Ministry of Health. Epidemiological bulletin, v. 47, n. 13, p. 1-15, 2016.

BRASIL. Ministry of Health. Secretariat of health surveillance. Department of epidemiological surveillance. Programa Nacional de Controle da Tuberculose. Brasília, DF: Ministry of Health; 2003.

CECÍLIO, Hellen Pollyana Mantelo; SANTOS, Aliny de Lima; MARCON, Sonia Silva; LATORRE, Maria do Rosário Dias de Oliveira; MATHIAS, Thais Aidar de Freitas; ROSSI, Robson Marcelo. Tendência da mortalidade por tuberculose no estado do paraná, Brasil - 1998 a 2012. Ciência e Saúde Coletiva, cidade, v. 23, n. 6, p. xx-xx, 2018.

COUTO, Davi Sarmento; CARVALHO, Rafael Nicolau; AZEVEDO, Elisângela Braga, MORAES, Marina Nascimento; PINHEIRO, Patrícia Geórgia Oliveira Diniz; FAUSTINO, Elaine Braga. Fatores determinantes para o abandono do tratamento da tuberculose: representações dos usuários de um hospital público. Saúde em Debate, cidade, v. 38, n. 102, p. 572-81, 2014.

FERREIRA, Magali Luzio; CASTILHO, Maria Augusta; OLIVEIRA, Edilene Maria. Brasil, Paraguai, Argentina e Chile / Rota Bioceânica: relações culturais no território vivido. Interações, Campo Grande, MS, v. 20, n. special, p. 69-89, 2019.

FREITAS, Wiviane; MATOS, Maria Torres, SANTOS, Crícia Cristina, SILVA, Monique Mesquita; ROCHA, Gabriela Amim. Perfil clínico-epidemiológico de pacientes portadores de tuberculose atendidos em uma unidade municipal de saúde de Belém, Pará, Brasil. Magazine Pan-Amazonica de Saúde, Ananindeua,PR, v. 7, n. 2, p. 45-50, 2016.

GASPAR, Renato Simões; NUNES, Natália; NUNES, Marina; RODRIGUES, Vandilson Pinheiro. Análise temporal dos casos notificados de tuberculose e de coinfecção tuberculose-HIV na população brasileira no período entre 2002 e 2012. Jornal Brasileiro de Pneumologia, Brasília, v. 42, n. 6, p. 416-22, 2016.

GIROTI, Suellen Karina de Oliveira; BELEI, Renata Aparecida; MORENO, Fernanda Novaes; SALOMÃO, Fernando. Perfil dos pacientes com tuberculose e os fatores associados ao abandono do tratamento. Cogitare Enfermagem, Curitiba, v. 15, n. 2, p. 271-7, 2010.

GOMES, Teresa. Tuberculose extrapulmonar: uma abordagem epidemiológica e molecular. 2013. Dissertation (Master's Degree in Infectious Diseases) - Federal University of Espírito Santo, Vitória, ES, 2013.

INSTITUTO BRASILEIRO DE GEOGRAFIA E ESTATÍSTICA. Diretoria de Pesquisas, Coordenação de População e Indicadores Sociais. Estimativas da população residente com data de referência 10 de julho de 2020. Rio de Janeiro: Instituto Brasileiro de Geografia e Estatística, 2020. Available at: https://cidades.ibge.gov. $\mathrm{br} / \mathrm{brasil} / \mathrm{ms} / \mathrm{campogrande/panorama.} \mathrm{Access} \mathrm{on:} 20$ June 2021.

MARQUES, Marli; RUFFINO-NETTO, Antônio; MARQUES, Ana Maria Campos; ANDRADE, Sônia Maria Oliveira; SILVA, Baldomero Anônio Kato; PONTES, Elenir Rose Jardim Cury. Magnitude da tuberculose pulmonar na população fronteiriça de Mato Grosso do Sul (Brasil), Paraguai e Bolívia. Cadernos de Saúde Pública, Rio de Janeiro, v. 30, n. 12, p. 2631-42, 2014.

NOTIFIABLE DISEASES INFORMATION SYSTEM (SINAN). Secretaria Estadual de Saúde. Portal SINAN, Campo Grande, MS, 2020. 
NOVONTY, Thomas; HENDRICKSON, Erick; SOARES, Elizabeth C. C.; SERENO, Andrea B.; KIENE, Susan M. HIV/AIDS, tuberculose e tabagismo no Brasil: uma sindemia que exige intervenções integradas. Cadernos de Saúde Pública, Rio de Janeiro, v. 33, n. 3, 2017.

OLIVEIRA, Marina Gribel; DELOGO, Karina Neves; OLIVEIRA, Hedi Marinho de Melo Gomes; RUFFINONETTO, Antonio; KRITSKI, Afranio Lineu; OLIVEIRA, Martha Maria. Anemia em pacientes internados com tuberculose pulmonar. Jornal Brasileiro de Pneumologia, Brasília, v. 40, n. 4, p. 403-10, 2014.

PEREIRA, Susan Martins Pereira; ARAÚJO, Gleide Santos de; SANTOS, Carlos Antônio de Souza Teles; OLIVEIRA, Maeli Gomes de; BARRETO, Maurício Lima. Associação entre diabetes e tuberculose: estudo caso controle. Revista de Saúde Pública, São Paulo, v. 50, n. 82, 2016.

SILVA, Gabriela Drummond Marques; BARTHOLOMAY, Patrícia; CRUZ, Oswaldo Gonçalves; GARCIA, Leila Posenato. Evaluation of data quality, timeliness and acceptability of the tuberculosis surveillance system in Brazil's micro-regions. Ciência e Saúde Coletiva, Rio de Janeiro, v. 22, n. 10, p. 3307-19, 2017.

WORLD HEALTH ORGANIZATION. Global tuberculosis control. Geneva: World Health Organization, 2011. Available at: httpp: www. who.int/tb/publications/global_report/2011/gtbr11_full.pdf. Access on: 20 June 2021.

\section{About the authors:}

João Pedro Arantes da Cunha: Graduated in Medical School at the State University of Mato Grosso do Sul (UEMS). E-mail: jparantesdacunha@gmail.com, Orcid: https://orcid.org/0000-0002-3292-0210

Rafael Vilela de Campos: Medical student at the Anhanguera-Uniderp University. E-mail: vilelacampos9@gmail.com, Orcid: https://orcid.org/0000-0002-9868-9509

Ruberval Franco Maciel: PhD in Urban Education at the City University of New York, United States. Doctorate in English Language and Literary Studies at the University of São Paulo (USP), with a doctoral internship at the Centre for Globalization and Cultural Studies of the University of Manitoba, Canada. Masters in Applied Linguistics at the University of Reading, England. Professor of the Languages department, both graduation and Post-Graduation programs, and of the Medical School of the State University of Mato Grosso do Sul (UEMS). Coordinator of the University Network of the Route of Latin American Integration (UniRila). E-mail: ruberval.maciel@gmail.com, Orcid: https://orcid.org/0000-0003-0373-1047

Ana Maria Campos Marques: Doctorate in Health and Development in the Southwest Region at the Federal University of Mato Grosso do Sul (UFMS). Masters in Collective Health at UFMS. Graduated in Medical School at the Federal University of Juiz de Fora (UFJF). Coordinator of the Tabagism Ambulatory of the Santa Casa of Campo Grande. Currently, is a professor of the Anhanguera-Uniderp University and of the Medical School department of the State University of Mato Grosso do Sul (UEMS). E-mail: camposmarquesanamaria52@gmail.com, Orcid: https://orcid.org/0000-0003-0982-6602 
